\title{
Study on the Effectiveness of the Policy Implementation on Disaster Mitigation of Mount Semeruin Lumajang, Indonesia
}

\author{
Suhari $^{1} \Varangle$ \\ Hary Yuswadi ${ }^{2}$ \\ Tatang Ary Gumanti ${ }^{3}$ \\ Syamsul Maarif ${ }^{4}$ \\ Doctoral Program at Faculty of Political and Social Sciences, Jember University, Indonesia \\ ${ }^{2, s, 4}$ Lecturer at Faculty of Political and Social Sciences, Jember University, Indonesia
}

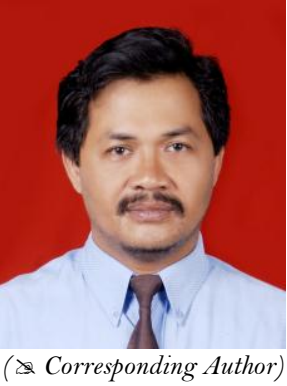

\begin{abstract}
This study focuses on evaluating the effectiveness of the policy implementation of disaster mitigation on mount Semeru in the district of Lumajang, East Java Province, Indonesia. It uses case study approach. The results of interviews with a number of key informant persons lead us to conclude that the policy implementation of disaster mitigation of mount Semeru is still not effective and less optimal. Many factors are identified as the causes, amongst other include network conditions and communication, slow and lack of government response, small funding allocation and realization, lack of coordination between the Government and the parties in Lumajang, low of stakeholders' participation, and weak of the Regional Representatives Council role to control the regent's performance in governance implementation. Serious efforts need to be in place in order to make the disaster management is warranted and secured.
\end{abstract}

Keywords: Policy, Disaster management, Mount semeru.

Citation | Suhari; Hary Yuswadi; Tatang Ary Gumanti; Syamsul Maarif (2017). Study on the Effectiveness of the Policy Implementation on Disaster Mitigation of Mount Semeruin Inojang, Management Studies, 4(2): 94-99.

History:

Received: 29 June 201

Revised: 17 July 2017

Accepted: 28 July 2017

Published: 1 August 2017

Licensed: This work is licensed under a Creative Commons

Attribution 3.0 License (cc) Ev

Publisher:Asian Online Journal Publishing Group
Contribution/Acknowledgement: All authors contributed to the conception and design of the study.

Funding: This study received no specific financial support.

Competing Interests: The authors declare that they have no conflict of interests.

Transparency: The authors confirm that the manuscript is an honest, accurate, and transparent account of the study was reported; that no vital features of the study have been omitted; and that any discrepancies from the study as planned have been explained.

Ethical: This study follows all ethical practices during writing.

\section{Contents}

1. Introduction

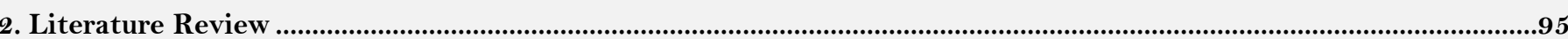

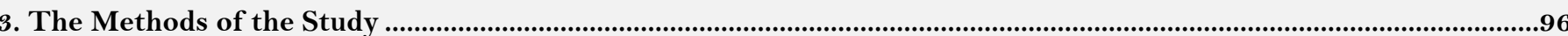

4. Results and Discussion ...................97

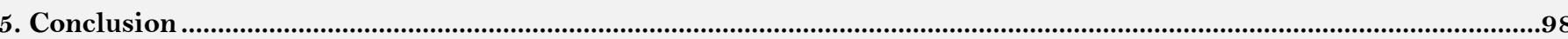

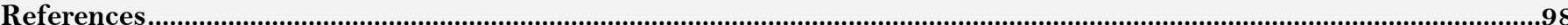

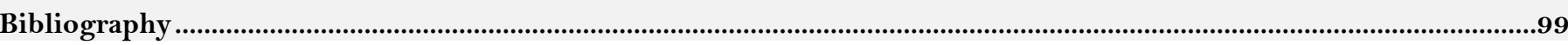




\section{Introduction}

The existence of disaster all this time is often understood by many people with misconceptions, especially those who live in the remote area. This misunderstading occurs because they put the disaster as a condition that emerges due to natural factors and that is beyond of human control. To overcome this improper mind set, the Indonesian government has responded by issuing Law Number 24 year 2007 on Disaster Management. Article 1 of the Law defines disaster:

"The events or series of events that threaten or disrupt the lives and livelihoods, whether caused by natural

factors and / or non-natural or human factors that lead to the emergence victims of human lives, environmental damage, loss of property, and the psychological impact".

The definition of disaster as stated in the Indonesian legislation is believed to provide better understanding about the disaster among all the related parties (stakeholders). As disaster is generally to be threatening and damaging (hazard) and vulnerable in the middle of the community, the implementation of Disaster Risk Reduction (DRR) becomes an important part of efforts to minimize the risk of disaster. At least in the case of hazard, the public is not too vulnerable. In this respect, the head of Indonesia National Bureau of Disaster Management, Maarif (2010) asserts that the community readinessto anticipate and to deal with disaster is improving as shown by the empowerment people efforts to have the ability and awareness to take the initiative in conducting rescue action.

The efforts to disenchant public about how to deal with hazards and disasters are already contained in the book of National Action Plan of Disaster Risk Reduction (NAP-DRR), which was launched on 24 January 2007 by the National Development Planning Institution (BAPPENAS) and the National Coordinating Agency on Disaster Management. Furthermore, to strengthen the DRR policy with regard to the supporting regulation, Indonesian government has issued several follow up regulations, such as:

1. Government Regulation Number 21 in 2007 on the Disaster Management.

2. Government Regulation Number 22 of 2007 on Financing and Disaster Relief.

3. Government Regulation Number 23 of 2007 on Role of Government Institutions and Foreign NonGovernment Institutions.

4. Minister of Health Decree Number 145 of 2007 on the Guidelines for Disaster Management and Disaster Mitigation.

As Indonesia has tens of provinces and hundreds of districts or Cities spread over thousand miles with more than 17,000 islands, surrounded with two biggest ocean and many active volcanoes, collaboration between the central government and local governments is needed. This collaboration is needed to support the DRR and the disaster management in the case of disaster. Disaster cannot be predicted and because of the geographic characteristics, Indonesia is said be vulnerable to large scale of disaster amongst other earthquake, tsunami, flood, typhoons, and volcano eruption. Thus, management of disaster and DRR is very important issues.

Mount Semeru is located in district of Lumajang. It is regarded as the most active volcano that can erupts at any time. It has erupted many times and most of the affected area is the district of Lumajang. Thus, to anticipate any possible eruption and its effect, the management of disaster caused by direct or indirect effects of mount Semeru, the local government has to be prepare. That is why, the management of disaster as well as the DRR is put in highly place.

This study focuses on evaluating the response of local government of the district of Lumajangin the effectiveness of the policy implementation on disaster mitigation of mount Semeru. Based on initial observations, it appears that the response of Lumajang Government of very slow. Referring to the issuance of Law number 24 year 2007, it took six years for the local government of Lumajang to publish the Regional Regulation Number 1 year 2013 about Disaster Management. The length of the period between the issuance of Law number 24 of 2007 and the Regional Regulation number 1 of 2013 is seen asindication that disaster management in the district of Lumajang is not a priority of the district development.

This paper is expected to provide inputs for the local government to deal with risk inherent in the mount Semeru related disasters. Mount Semeru is regarded as the most active volcano in the world and its eruption impact could be nightmare for people living in surrounding are and the environment.so, the government, in particular the local government, has to have a clear and fixed policy in dealing with the disaster management related to mount Semeru.

\section{Literature Review}

\subsection{The Disaster Policy Implementation}

A policy shall be implemented to ascertain good government and seriousness of the government in serving the community. As expressed by Patton et al. (2012) the policy shall be implemented in order to solve any problem faced by the stakeholders. In this respect, Patton and Sawicki assert that implementation deals with a variety of activities that is geared to realize the programs. In this respect, the executives set out to organize, interpret and implement policies that have been selected. However, prior to setting the policy, a comprehensive study shall be carried so to make sure that the policy is well defined. Tangkilisan (2003) also advocates the importance of implementing the policy. The policy is not kept in the table. It shall be provided to the community.

The executive agencies have the mandates to execute the policy in most effective and efficient ways. This is carried by using all available resources. Dunn (1994) argues that the policy implementation is the implementation of the policy actions control in a certain period of time. Thus, the policy implementation is the implementation of policy actions control in a certain time.

The policy implementation in the disaster management is the focus of this study. Point 9 of Article 1 of Chapter I of the Law number 24 of 2007 defines disaster mitigation as "The effort to reduce disaster risk, either through physical development as well as awareness and developing ability in facing the threat of a disaster". Thus, disaster mitigation has two systems, namely the structural mitigation and non-structural mitigation. The structural mitigation is an effort to minimize the disaster through the development of a variety of physical infrastructure and using technological approaches, such as creating a channel, a detector volcanic activity, earthquake-resistant buildings, or Early Warning System, which is used to predict a volcanic disaster. The non- 
structural mitigation is an effort to reduce the impact of disasters, not classified as the physical effort. The nonstructural mitigation can be done by making the urban planning, community capacity building, legislation, regional planning, and insurance.

The mitigation policies either structural or non-structural should mutually support each other. The usage of technology to predict, anticipate and reduce the risk of a disaster must be supported by the creation and enforcement of an adequate regulatory framework that is backed up by the appropriate spatial plan.

Some studies have been done on volcanic disasters, for example Suhardjo (2011); Juhaeni (2016) and Lestari et al. (2016). There are some dangers that may occur accidentally during a volcanic eruption. The main (primary) danger from the volcanic eruptions is a hot cloud (pyroclastic flow), stones hurling (incandescent), heavy ash rain, flowing of lava (lava flow), and toxic gases. The secondary danger of volcanic eruptions is an accumulation of material in various sizes at the summit and upper slopes. In the rainy season, most of the material will be carried away by rainwater and it creates the mud dough which turns down to the valley as rocks flood or other types of flood.

\subsection{Model Policy Implementation}

Policy implementation model varies that it depends on the environment. In addition, the process to carry out has also variation. Van Meter and Van Horn (1975) assert that the differences in the implementation process will be influenced by the policies' charater that will be implemented. Winarno (2007) and Wahab (2008) summarize a number of aspects of policy implementation based on the model proposed by Van Meter and Van Horn. The following describes the intended aspects.

The first aspect is the size and the purpose of the policy. In the policy implementation, size and purposes of the policy is an image of the direction of the policy that will bring a change in the society. According to Van Meter and Van Horn (1975) the achievement indicators identification is a crucial stage in the policy implementation analysis. The achievement indicators assess the extent of basic measures and policy purposes that have been realized. Basic measures and goals are useful in representing all of goals of policy decisions. In addition, the basic measures and purposes are the evidence itself and can be easily measured in some cases.

The second aspect is the policy resources. Van Meter and Van Horn (1975) explain that besides the basic measures and policy targets, we should pay more attention on the available resources. The sources could be in terms of funds or other incentive which encourage and facilitate effective implementation.

The third aspect is communication between related organizations and implementation activities. According to Van Meter and Van Horn (1975) successful implementation often requires fixed mechanisms and procedures of the institution. It is actually executed to encourage a greater possibility for high officials to encourage the executive to act in a consistent event with the basic measures and policy goals. The officials must possess power as measured by first, recruitment and selection, second, giving an assignment and relocation, third, promotion, and fourth, the dismissal.

The fourth aspect is the characteristics of the implementing agency Van Meter and Van Horn (1975) present some elements that may affect the organization in implementing the policy. They include competition and the staff size of an institution, the hierarchical control levels toward the decisions of the sub units and processes in implementing agencies, political resources of an organization (e.g. support among members of the legislative and executive), the vitalization of an organization, the level of communications "opened", which is defined as a network of horizontal and vertical communication freely and the degree of freedom that are relatively high in communication with individuals outside the organization, and the formal and informal link an entity "decision maker" or "executive of decision".

The fifth aspect is related to the economic, social and political conditions. The impact of economic, social and political conditions on public policy is the center of attention. Yet, the impact of these factors in the implementation receives a little attention. According to Van Meter and Van Horn (1975) these factors may have a profound effect on the achievement of the implementing agencies.

The sixth aspect is the tendency of the implementers. Van Meter and Van Horn (1975) argue that every component of the model that is discussed above must be filtered through the implementers' perceptions of the jurisdictions in which that policy is produced. The tendencies directions towards the basic measures and goals are also a very important thing. The executor may fail to execute the policies precisely because they reject the goals which are contained in those policies. On the contrary, the reception on basic measures and policy purposes is accepted widely by the policy implementers that will be a support for the successful policy implementation.

A study by Juhaeni (2016) shows that in the case of eruption of mount Merapi, another most active volcano in the Java island of Indonesia, the involvement of many parties is crucial to support the disaster management. Juhaeni identifies a number of key elements. Yet, the most common elements of community involvement include partnership, participation, empowerment, and the local people ownership. Nevertheless, Juhaeni notices that when the disaster management efforts are sustainable at individual and community level, there will be difficulty in alleviating or reducing the losses and scale of the tragedy. A similar conclusion is also advanced by Lestari et al. (2016) in their study of the impact of eruption of Mount Sinabung in West Sumatera in the island of Sumatera.

Another study reveals the importance of education (Suhardjo, 2011). His study focuses on the mount Merapi eruption and he advocate the use of education either formal or informal to strengthen the community awareness for risk reduction in the case of eruption. Suhardjo comes to conclude that involvement of various parties to educate the people is a must.

\section{The Methods of the Study}

This study uses qualitative approach in an attempt to evaluate the effectiveness of policy implementation with regard to disaster mitigation of mount Semeru. A number of key informants were interviewed to gain knowledge and understanding on the effectiveness of policy implementation in an attempt to manage disaster and to reduce risk related to the eruption and potential eruption of mount Semeru. 


\section{Results and Discussion}

The effectiveness study of the policy implementation disaster mitigation of mount Semeru in Lumajang is influenced by many factors, either internal factors or external factors. The following are descriptions of the factors known to be associated with the DRR and disaster management.

\subsection{Poor Network and Communication Line Condition on Disastrous Areas}

The role of communication in disaster mitigation policy implementation on mount Semeru is important, whether it is done by the government to the public, or the conversely. Conveying information quickly is one of the ways to support disaster mitigation on mount Semeru effectively, because often the disasters escalation vulnerability at mount Semeru increases. However, it was found that the implementation of the communication process in building a network and disastrous areas communication lines is still very weak. There are two causes leading to that weak network. Firstly, the communications done by local government of Lumajang is mainly carried out by the Local Disaster Management Agency (LDMA) in sharing the information. In addition, reducing the stiffness in the disaster mitigation process is still not done effectively. The indication of that is that it is very often a miscommunication between LDMA and societies in disastrous-prone areas, especially periodic information about disaster escalation of mount Semeru. Secondly, local government of Lumajang is not responsive, especially the LDMA in decision-making and communication systems building with other disaster care institutions. Establishing communication with other disaster care institutions is important, as a part of the synergies and it will minimize the casualties when there is a disaster on mount Semeru.

It is not easy to manage disaster in a synergistic perspective. They need to build the effective communication among government agencies or with some parties. But, this is the biggest challenge for local government of Lumajang in disaster mitigation implementation of mount Semeru. It is not a secret anymore, that the coordination problems in governance is not uncommon. One possible reason for this is that there is unclear "job description" of governmental agencies, often handcuffed by the lack of communication between governmental and nongovernmental institutions.

\subsection{Slow Response of Local Government}

Local government of Lumajang is the spearhead of the disaster mitigation process of mount Semeru and it should be more responsive than the other parties. But, in the empirical facts, the response of the local government is still very slow. It can be indicated from the lack of Regional Regulation related to disaster mitigation, particularly in mitigation of mount Semeru. The regulation is important to ensure that disaster mitigation process is in accordance with the needs of local society, especially peoples who live in disastrous prone areas around the mountain of Semeru.

The study finds that susceptibility toward the eruption potential of mount Semeru is very high. That is due to the establishment of disastrous-prone areas become a settlement, the destruction of vegetation cover-up in mount Semeru disastrous-prone areas. On the other hand, the population density in the disastrous-prone areas continue to grow and they are lack of understanding toward the threat of mount Semeru eruption disaster.

Based on data from the LDMA, during 2010-2013 period, mount Semeru had erupted 181 times, either in small and medium scale. This is of course a threat. This threat is considered to be chronic, and the local government shall ready to response and anticipate for any possible worst condition. The government shall make policy response, provide human resources and offering facilities and infrastructure of disaster mitigation.

\subsection{Lack of Funding Allocation and Realization}

The lack budget for disaster mitigation allocation, especially in disaster mitigation of mountSemeru. Low allocation of funds for disaster mitigation is not in the spirit as amended by Law number 24 year 2017 on Disaster Management, especially Article 61 urging the government and local governments to allocate the adequate disaster management funds. The adequate Context for disastrous-prone areas such as Lumajang shall be the same as the allocation foreducation budget, that is 20 percent of the total budget. However, in practical, the budget for disaster management institutions such as LDMA is still very minimal.

\subsection{Lack of Mitigation Policy Implementation}

Another weakness in the implementation of disaster mitigation policy is that it is too elitist and without involving many parties. So many parties, particularly the public are indifferent to the program implemented by the government of Lumajang, through the LDMA, such as the simulation program of disaster mitigation of mount Semeru on October 17, 2015. The parties involved in the program are from the local government of Lumajang and parties outside disastrous-prone areas. That condition makes it seem indifferent and its existence is ignored by the government of Lumajang. Even the negative perception of the public on disastrous-prone areas of mount Semeru that the program is purely project only, without wanting to resolve the real problem, namely the risk mitigation of mount Semeru.

In this case, there ought to be a real action of the implementation process of disaster mitigation policy of Mount Semeru. Thus it needs the stakeholders' engagement and public participation. In the macro context, this concept is often called the deliberative policy. In the deliberative policy, the policy implementation done jointly between the parties facilitated by the experts to ensure that the policies are implemented according to the plan and the public's desire. The involvement of citizens or citizen engagement is the core of deliberative policy implementation. The stakeholder engagement and public participation is still very minimal and is dominated by a handful of interest groups only. The deliberative policy is demanding and force a real solution in every implementation of policies, particularly in the policies implementation of disaster mitigation of mount Semeru. 


\subsection{Absence of Regional Legal Products}

The absence of local regulations of products related to disaster management in Lumajang. The condition is very alarming because the district has the disaster threat of mount Semeru that quite vulnerable, which at any moment it can be threatening and the safety of citizens in disastrous-prone areas of mount Semeru is in danger.

\subsection{Lack of Coordination of Various Parties}

Lack of coordination between the local government of Lumajang and the interested parties and the reluctance of local governments to cooperate with the parties is reinforcing the impression that the local government has not been able to run the principle of good governance.

\subsection{Low Stakeholders Participation}

The participation of the stakeholders in disaster mitigation is considered to be low. Here seems to be less respect among stakeholders to participate in disaster mitigation and this has been known as the causes of disaster mitigation remain stagnant and less optimal. In fact, one of the officials in LDMA in Lumajang confuses with the disaster mitigation at this time. On the other hand, when the LDMA apparatus has strong enthusiasm to work, the support of the executing parties of the district is minimal. Even, it impresses that the LDMA of Lumajang has been used as a "discharge" the bureaucrats who considered not as an idea with the elite local government.

\subsection{Disaster Management is Not Inserted into the Regional Medium Term Development Plan}

Disaster management has not been inserted into the Regional Medium Term Development Plan (RMTDP) as one of the priority programs. Whereas, the RMTDP has significance to every policy, because RMTDP includes the vision, mission, and program of the region head, local development strategy, public policy, and other work plan.

\subsection{Weak of Regional Representatives Council Role}

The weak of Regional Representatives Council's role to control the regent's performance of the governance's implementation program particularly in disaster mitigation of mount Semeru. This can be evidenced in the case of disaster mitigation of mount Semeru, which so far the parliament has not been able to push to become a priority to be executed quickly nor has not initiated a disaster management into the Regional Legislative Program. On the other hand, weak of oversight function of Parliament in Lumajang is very common. This is caused by a number of issues that include the following. First is the norms that is governing the implementation of the oversight function of Parliament put the Parliament in the weak position that it is only as the party who discusses the supervision. Second is the capability of the legislators has not been maximal in the monitoring field, so they seem to put the legislators as the audiences. Third is the lack of communities' involvement in each of controlling by parliament in Lumajang.

\section{Conclusion}

This study evaluates the effectiveness of the policy implementation of disaster mitigation of mount Semeru in the district of Lumajang. We find that the implementation is still not effective and optimal. There are a number of factors that lead this inadequate implementation of policy for risk and disaster management of mount Semeru. The followings are our main findings.

1. Network conditions and communication lines of disaster area are not good enough to make disaster mitigation mechanisms work synergistically and be well coordinated.

2. The lack of the local government's response to mitigate the disaster.

3. Less than adequate of funding allocation and realization in disaster mitigation.

4. The implementation of disaster mitigation policies tends to be elitist and seems to be made just for the sake of the project, without addressing to the underlying problem.

5. The absence of local regulations products related to disaster management.

6. Lack of coordination between the local government and other interested parties.

7. Lack of stakeholders' participation in disaster mitigation.

8. Disaster management has not been inserted into the Regional Medium Term Development Plan as one of the priority programs.

9. Weak of the Regional Representatives Council's role in controlling the district's performance in governance implementation of disaster mitigation.

\section{References}

Dunn, W.N., 1994. Public policy analysis: An introduction. New Jersey: Pearson Education.

Juhaeni, J., 2016. Strategies for community empowerment in mount Merapi disaster of central Java Province Indonesia. International Journal of Social Sciences, 43(1): 24-41.

Lestari, P., E.T. Paripurno, S.B. Kusumayudha and B. Ramadhaniyanto, 2016. Komunikasi Lingkungan Untuk Mitigasi Bencana Erupsi Gunung Sinabung. Jurnal ASPIKOM, 3(1): 56-64. View at Google Scholar | View at Publisher

Maarif, S., 2010. Bencana dan Penanggulangannya Tinjauan dari Aspek Sosisologis. Jurnal Dialog Penanggulangan Bencana, 1(1): 1-7. View at Google Scholar

Patton, C., D. Sawicki and J. Clark, 2012. Basic methods of policy analysis and planning. New York: Prentice Hall.

Suhardjo, D., 2011. Arti Penting Pendidikan Mitigasi Bencana Dalam Mengurangi Resiko Bencana. Cakrawala Pendidikan, 30(2): 174-188. View at Google Scholar

Tangkilisan, H.N.S., 2003. Implementasi kebijakan publik transformasi Pikiran George Edwards. Yogyakarta: Lukman Offset.

Van Meter, D.S. and C.E. Van Horn, 1975. The policy implementation process. A conceptual framework. Administration and Society, 6(4): 445-488. View at Google Scholar

Wahab, S.A., 2008. Analisis Kebijaksanaan: Dari Formulasi ke Implementasi Kebijaksanaan Negara. Jakarta: Sinar Grafika.

Winarno, B., 2007. Kebijakan Publik: Teori dan Proses. Yogyakarta: Media Pressindo. 


\section{Bibliography}

Government, 2007. Government Regulation No. 21 Year 2007 on the Implementation of Disaster Management.

Government, 2007. Government Regulation No. 22 Year 2007 on Financing and Disaster Relief

Government, 2007. Government Regulation No. 23 year 2007 on the Role of Government and Foreign Non-Government agencies.

Local, 2013. Local Government of Lumajang Rule Number 1 of 2013 about the Disaster Management.

The Indonesian, 2007. The Indonesian Law Number 24 Year 2007 on Disaster Management. 